\title{
Young humpback whale Megaptera novaeangliae feeding in Santa Catarina coastal waters, Southern Brazil, and a ship strike report
}

\author{
Guilherme Augusto Bortolotto ${ }^{1,2^{*}}$, Cristiane Kiyomi Miyaji Kolesnikovas ${ }^{1}$, Andrea Santarosa Freire ${ }^{3}$ \\ and Paulo César Simões-Lopes ${ }^{4}$
}

\begin{abstract}
Background: Humpback whales Megaptera novaeangliae are cosmopolitan and highly migratory animals that rarely feed in low latitude waters during their breeding seasons. The western South Atlantic humpback whale population breeds off the Brazilian coast, from Natal $\left(4^{\circ} \mathrm{S}\right)$ to Cabo Frio $\left(23^{\circ} \mathrm{S}\right)$ and migration to their feeding grounds is known to be undertaken through offshore waters.

Results: Here we report on an unusual stranding of a young humpback whale that was feeding in the coastal waters of Santa Catarina state $\left(27^{\circ} \mathrm{S}\right)$, in October 2014. Evidence of a ship strike and that the animal had fed in no more than a few hours before death are also presented. Additionally, it is the first time that Peisos petrunkevitchi, a sergestid shrimp species, is described as prey for large whales.

Conclusions: Although more information is required before we can further discuss whether the area could provide an important source of food for young humpback whales, the present ship strike highlights a possibly important threat in case this ecological feature is confirmed in the future.
\end{abstract}

Keywords: Large whale, Migration, Peisos petrunkevitchi, Prey, Distribution, Western South Atlantic

\section{Background}

Cosmopolitan and highly migratory animals, humpback whales Megaptera novaeangliae (Borowski 1781) are rarely observed feeding in low latitude waters during their annual breeding season (Clapham 2000). An exception is the population inhabiting the Arabian Sea that does not migrate (Pomilla et al. 2014). At-sea observations and data from stranded animals indicate that they normally feed in high-latitude regions during summer and autumn months (Mackintosh 1942; Chittleborough 1965; Dawbin 1966; Clapham 2000). Although this seems to remain a general pattern for humpback whale populations around the world, increasing records in recent years have reported

\footnotetext{
*Correspondence: bortolotto.vet@gmail.com

'Associação R3 Animal, Parque Estadual do Rio Vermelho, Barra da Lagoa, Florianópolis, SC 88061-500, Brasil

${ }^{2}$ Sea Mammal Research Unit - SMRU, Scottish Oceans Institute, University of St. Andrews, St. Andrews, Fife KY16 8LB, UK

Full list of author information is available at the end of the article
}

animals feeding beyond their usual feeding grounds and seasons, and during migration (e.g. Stone et al. 1987; Baraff et al. 1991; Gendron and Urbán 1993; Swingle et al. 1993; Best et al. 1995). In Brazil, Alves et al. (2009) reported humpback whales lunge-feeding near an oil platform, and Danilewicz et al. (2009) presented evidence of feeding in coastal waters from a young female that stranded in the coast of Rio Grande do Sul state $\left(\sim 29^{\circ}\right)$.

Humpback whales of the western South Atlantic (WSA) population breed in the Brazilian coast during winter and spring months, and their main concentration site is the Abrolhos Bank $\left(16^{\circ} 40^{\prime}-19^{\circ} 30^{\prime} \mathrm{S}\right)$ (Martins et al. 2001; Andriolo et al. 2010), a wide portion of the Brazilian continental shelf. According to satellite-tagging studies (Zerbini et al. 2006), during this period their range of occurrence comprises the continental shelf, i.e. from the shore to the shelf-break, with a latitudinal distribution from Cabo Frio $\left(\sim 23^{\circ} \mathrm{S}\right)$, in Rio de Janeiro state, to 
Natal $\left(\sim 4^{\circ} \mathrm{S}\right)$, in Rio Grande do Norte state (Fig. 1). That study also indicates that these whales use offshore waters for migration, when they travel to feeding grounds off South Georgia and South Sandwich islands. The coast of Rio de Janeiro state therefore represents their southern limit of departure. Coastal occurrence of animals further south is to be considered unusual for Brazil. There are few records of humpback whales in the southern coast of the country (e.g. Danilewicz et al. 2009), and although they have been observed in the coast of Santa Catarina (Cherem et al. 2004), their presence remains rare (personal observation C.K.M.K and P.C.S.L.). Here we report on an unusual stranding of a young humpback whale in Santa Catarina state, the presence of food items in its stomach and a ship strike as the cause of death.

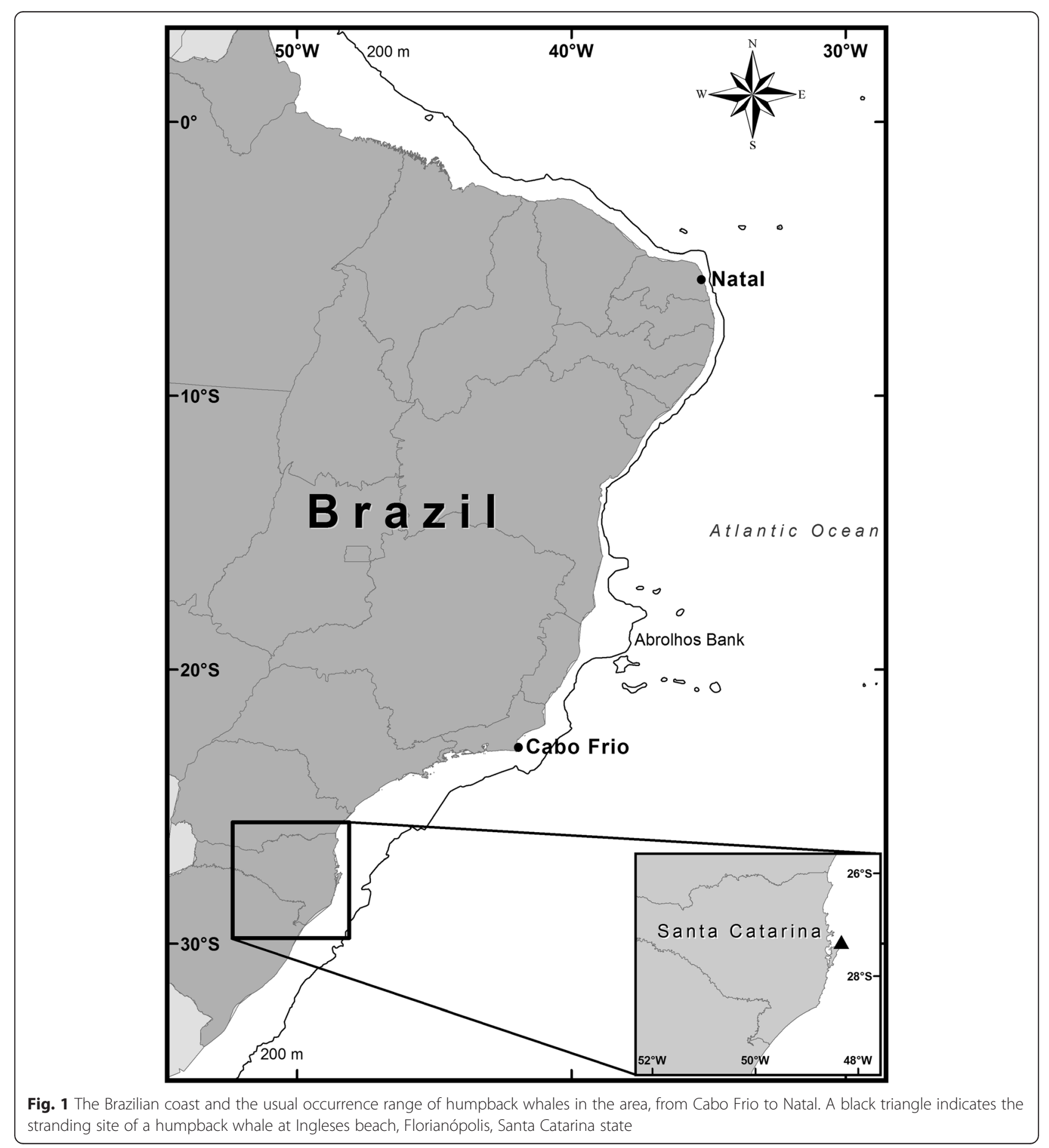




\section{Methods and results}

A dead female humpback whale was found stranded on $16^{\text {th }}$ October 2014 , at Ingleses beach $\left(27^{\circ} 26^{\prime} 27.6^{\prime \prime} \mathrm{S}, 048^{\circ}\right.$ 22'26.4"W) in Florianópolis, Santa Catarina, southern Brazil (Fig. 1). The $8.36 \mathrm{~m}$ long carcass (total length) was in good condition and did not show any clear external signs of interaction with human activities (e.g. fishing gear marks). Cookie-cutter shark wounds, live whale lice and live barnacles were present on the body's surface. Necropsy revealed an evident hematoma (Fig. 2) on the right side of the body, extending from the thoracic to the abdominal muscular layers. When the abdominal cavity was accessed from its caudal edge, far from large veins or arteries, a large amount of blood flowed indicating internal haemorrhage. Examination of stomach contents revealed a great amount of undigested small shrimp-like crustaceans. The whale's biological samples are deposited in the collection of mammals of the Universidade Federal de Santa Catarina (Federal University of Santa Catarina) under number UFSC1422.

\section{Discussion}

Although stranding sites can be at considerable distance from where death occurred, as a consequence of ocean currents and wind drift (Peltier et al. 2012), the fresh condition of the carcass strongly indicates that the animal died within a few hours of when it was found. Moreover, the approach of Víkingsson (1997) on the "mean time of passage of food from the fore-stomach to the fundic chamber" for fin whales, as adopted by Danilewicz et al. (2009), supports the contention that the animal was alive and also feeding in no more than about 10 hours prior to death. Additionally, the presence of live whale lice indicates that the stranding occurred in less than three days
(Leung 1976), and the general aspect of skin was compatible with the previous conclusions. Furthermore, the site of stranding is in a residential area and there is no doubt that the carcass had beached on the day it was recorded.

The prey items were identified as Peisos petrunkevitchi (Fig. 3) (Burkenroad 1945) (Decapoda: Sergestidae) by A.S.F. at the Crustacean and Plankton Laboratory and are deposited in the biological collection of the Universidade Federal de Santa Catarina (number LCP/ECZ/UFSC101). This small shrimp species occurs from Rio de Janeiro state to Península Valdés $\left(44^{\circ} \mathrm{S}\right)$, in Argentina (Ruiz and Fondacaro, 1997; D'Incao and Martins 2000). Danilewicz et al. (2009) described another sergestid species, Acetes americanus (Ortmann 1893) as the main prey item for the stranded humpback whale reported for Rio Grande do Sul, $250 \mathrm{~km}$ further south. Both species are small pelagic shrimps that occur in coastal waters up to $50 \mathrm{~m}$ deep and their distributions overlap in the southern coast of Brazil (D'Incao and Martins 2000). Dense patches of P. petrunkevitchi are likely to be ideal for large planktivore whales to feed (Nicol 2006) since sergestid shrimps are already known to support the energetic demands of other large planktivorous animals such as whale sharks (Rohner et al. 2015). Because A. americanus and P. petrunkevitchi inhabit the pelagic realm, they probably present equivalent potential to be preyed on by whales in the coastal waters of southern Brazil. Besides the inclusion of $P$. petrunkevitchi in the list of recorded species preyed on by humpback whales, the current report suggests a new contribution of the shrimp as prey in Brazilian waters, being already described as an important food source for sciaenid fishes (Pombo et al. 2013) and wasp jellyfish (Nogueira Jr and Haddad 2008) in the area.

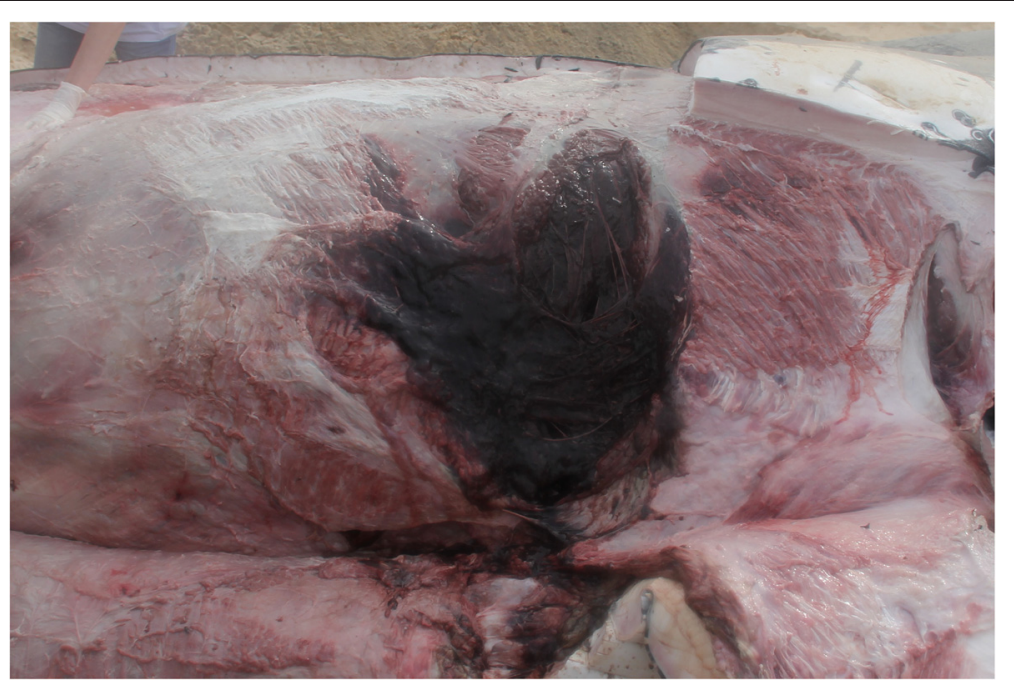

Fig. 2 Hematoma on the right side of a humpback whale carcass, in the thoracic/abdominal muscular layers. The whale carcass is facing right. (Picture: R3 Animal) 


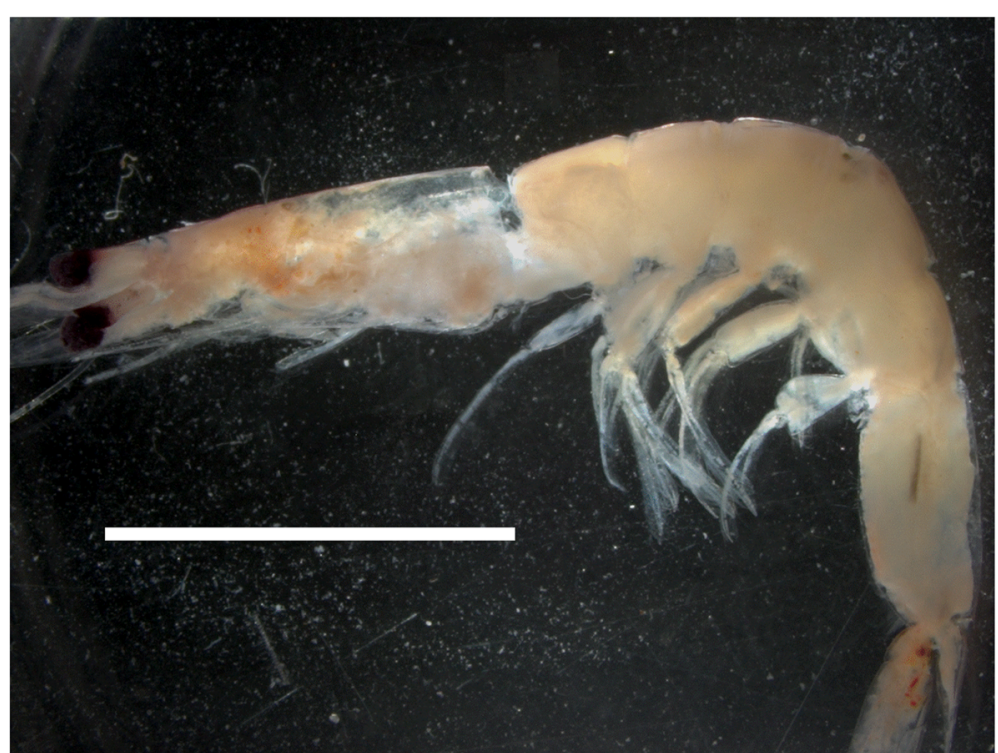

Fig. 3 Peisos petrunkevitchi collected from the stomach of a stranded humpback whale. The horizontal bar represents $1 \mathrm{~cm}$. (Picture: Thais Peixoto Macedo, LCP/UFSC)

The total length of the stranded animal $(8.63 \mathrm{~m})$ suggests that it was a juvenile, since this size corresponds to a one year old humpback whale (Clapham et al. 1999). Humpback whales at this age are usually approaching independence from their mother (Clapham et al. 1999) and this young animal could be starting to prey on crustacean after being recently weaned. The feeding may therefore have been opportunistic as a result of a large patch of prey being encountered. Also, large amounts of $P$. petrunkevitchi were found beached near the stranding site in the previous and following years (personal observation A.S.F.) so it is likely that the shrimp was abundant in the area in the year of the stranding.

Regarding the presence of this young whale in the coast of Santa Catarina, an important point to consider is that migration between breeding and feeding grounds for this population is known to be undertaken through offshore waters (Zerbini et al. 2006). Since the present stranding occurred after the usual peak of humpback whales occurrence along the Brazilian coast (Martins et al. 2001; Andriolo et al. 2010), most animals would have departed or were about to depart to their feeding area. Therefore the present animal could have started its migration but using a coastal route when travelling southwards instead. Because younger animals are less capable of accumulating energy reserves due to their smaller bodies, they also have a reduced capacity for spending long periods without feeding (Craig et al. 2003). For that reason, a coastal route that permits the animals to feed before travelling through areas where they are more unlikely to find food (i.e. offshore migratory regions) could be very profitable, if not essential, for a young whale.
Another possibility is that this young and sexually immature (i.e. incapable of reproducing) whale did not go to the population's usual breeding area on that season, but to an alternative habitat where it could feed during winter and spring (Swingle et al. 1993). Little is known, however, about specific feeding habitats for young animals of this population and more information is needed before we can determine if the present area may provide them with an important source of food.

The humpback whale population that inhabits the coast of Brazil has been showing clear signs of recovery since being severely depleted by commercial whaling in the mid-1900s (e.g. Ward et al. 2011; Zerbini et al. 2011; Bortolotto 2014). A proportional increase in their interactions with human activities is therefore expected, and ship strikes are recognized as an important threat to marine mammals in the Southern Hemisphere (Van Waerebeek et al. 2007) and around the world (Laist et al. 2001; Carrillo and Ritter 2010; Martins et al. 2013). In a recent study, the potential risk of ship strikes on humpback whales at the Abrolhos Bank was estimated (Bezamat et al. 2014) and the authors indicated that, depending on the vessels speed for example, the risk of whales being impacted by vessels in that area was very high. Although the density of whales in the present area is much lower than in the Abrolhos Bank, individual whales are subject to the risk of being struck when in areas of shipping traffic as the coastal regions of Santa Catarina. The characteristic haematoma in the body region most likely to be hit when the animal was alive (Laist et al. 2001), together with signs of internal haemorrhage strongly indicate that the present animal suffered a very strong impact 
that caused its death. Only a ship strike would explain such an impact.

\section{Conclusions}

This is the northernmost record of food items for a stranded humpback whale ever found in Brazil, and it constitutes strong evidence of feeding in the coastal waters of Santa Catarina $\left(27^{\circ} \mathrm{S}\right)$, far beyond the usual feeding grounds of the western South Atlantic population. The evidence of a fatal ship strike indicates a potential threat, particularly if future observations confirm that the area is regularly used by at least a portion of these animals (e.g. young individuals). It is also the first time Peisos petrunkevitchi is described as prey for large whales, expanding the current knowledge on the possible trophic roles of this crustacean species. Although more information is needed before we can make robust inferences concerning the ecological importance of the coastal waters of southern Brazil for humpback whales, the findings presented here highlight important conservation concerns.

\section{Abbreviations}

cm, centimetre; km, kilometre; LCP/UFSC, Laboratório de Crustáceos e Plâncton (Crustacean and Plankton Laboratory), Universidade Federal de Santa Catarina; m, metre; WSA, Western South Atlantic

\section{Acknowledgements}

The authors would like to thank the staff of the Aquatic Mammals Laboratory of the Federal University of Santa Catarina (LAMAQ) and the R3 Animal Association for their help during necropsy procedures. The municipality of Florianópolis provided logistical support. Two anonymous reviewers and Dr Matt Frost provided important comments on the final version of this manuscript.

\section{Funding}

This study was a collaborative work between the Universidade Federal de Santa Catarina and R3 Animal Association, and all the costs were covered by both institutions.

\section{Availability of supporting data}

The dataset supporting the conclusions of this article is included within the article as photographs.

\section{Authors' contributions}

CKMK and GAB conducted the necropsy, took photographs and collected samples. ASF identified the prey item. ASF, CKMK, GAB and PCSL wrote the manuscript together. All authors have read and approved the final version of the manuscript.

\section{Authors' information}

CKMK and GAB have degrees in veterinary medicine.

\section{Competing interests}

The authors declare that they have no competing interests.

\section{Ethics approval and consent to participate}

This work was conducted under the permission number 24110-4 (SISBIO ICMBio).

\section{Author details}

'Associação R3 Animal, Parque Estadual do Rio Vermelho, Barra da Lagoa, Florianópolis, SC 88061-500, Brasil. ${ }^{2}$ Sea Mammal Research Unit - SMRU, Scottish Oceans Institute, University of St. Andrews, St. Andrews, Fife KY16 8LB, UK. ${ }^{3}$ Departamento de Ecologia e Zoologia, Laboratório de Crustáceos e Plâncton, Universidade Federal de Santa Catarina, Florianópolis, SC
88040-900, Brasil. ${ }^{4}$ Departamento de Ecologia e Zoologia, Laboratório de Mamíferos Aquáticos - LAMAQ, Universidade Federal de Santa Catarina, CP 5102, Florianópolis, SC 88040-970, Brasil.

Received: 24 May 2016 Accepted: 3 June 2016

Published online: 13 July 2016

\section{References}

Alves LCPS, Andriolo A, Zerbini AN, Pizzorno JLP, Clapham PJ. Record of feeding by humpback whales (Megaptera novaeangliae) in tropical waters off Brazil. Mar Mam Sci. 2009:25:416-9.

Andriolo A, Kinas PG, Engel MH, Martins CCA, Rufino AM. Humpback whales within the Brazilian breeding ground: distribution and population size estimate. Endanger Species Res. 2010;11:233-43.

Baraff LS, Clapham PJ, Mattila DK, Bowman RS. Feeding behavior of a humpback whale in low latitude waters. Mar Mam Sci. 1991;7:197-202.

Best PB, Sekiguchi K, Findlay KP. A suspended migration of humpback whales Megaptera novaeangliae on the west coast of South Africa. Mar Ecol: Prog Ser. 1995;118:1-12.

Bezamat C, Wedekin L, Simões-Lopes PC. Potential ship strikes and density of humpback whale in the Abrolhos Bank breeding ground, Brazil. Aquat Conserv 2014; doi:10.1002/aqc.2523

Borowski GH. Gemeinnüzige naturgeschichte des thierreichs. Berlin: Gottlieb August Lange; 1781.

Bortolotto GA. Estimativas de abundância e tamanho de grupo de baleias-jubarte em transectos lineares na costa Brasileira, Master's thesis. Ilhéus: Universidade Estadual de Santa Cruz; 2014.

Burkenroad MD. A new sergestid shrimp (Peisos petrunkevitchi, n. gen., n. sp.), with remarks on its relationships. Trans Conn Acad Arts Sci. 1945;36:553-91.

Carrillo M, Ritter F. Increasing numbers of ship strikes in the Canary Islands: proposals for immediate action to reduce risk of vessel-whale collisions. J Cetac Res Manage. 2010;11:131-8.

Cherem JJ, Simões-Lopes PC, Althoff S, Graipel ME. Lista dos mamíferos do estado de Santa Catarina, Sul do Brasil. Mastozool Neotrop. 2004;11:151-84.

Chittleborough RG. Dynamics of two populations of the humpback whale, Megaptera novaeangliae (Borowski). Aust J Mar Freshw Res. 1965;16:33-128.

Clapham PJ. The humpback whale: seasonal feeding and breeding in a baleen whale. In: Mann J, editor. Cetacean societies: Field studies of dolphins and whales. Chicago: University of Chicago; 2000. p. 173-96.

Clapham PJ, Wetmore SE, Smith TD, Mead JG. Length at birth and at independence in humpback whales. J Cetac Res Manage. 1999;1:141-6.

Craig AS, Herman LM, Gabriele CM, Pack AA. Migratory timing of humpback whales (Megaptera novaeangliae) in the central North Pacific varies with age, sex and reproductive status. Behaviour. 2003;140:981-1001.

D'Incao F, Martins STS. Brazilian species of the genera Acetes H. Milne Edwards, 1830 and Peisos Burkenroad, 1945 (Decapoda: Sergestidae). J Crust Biol. 2000;20:78-86.

Danilewicz D, Tavares M, Moreno IB, Ott PH, Trigo CC. Evidence of feeding by the humpback whale (Megaptera novaeangliae) in mid-latitude waters of the Western South Atlantic. Mar Biodivers Rec. 2009;2:e88.

Dawbin WH. The seasonal migratory cycle of humpback whales. In: Norris KS, editor. Whales, dolphins and porpoises. Berkeley: University of California; 1966. p. 145-70.

Gendron D, Urbán J. Evidence of feeding by humpback whales (Megaptera novaeangliae) in the Baja California breeding ground, Mexico. Mar Mam Sci. 1993;9:76-81.

Laist DW, Knowlton AR, Mead JG, Collet AS, Podestà M. Collisions between ships and whales. Mar Mam Sci. 2001;17:35-75.

Leung YM. Life Cycle of Cyamus scammoni (Amphipoda: Cyamidae), ectoparasite of gray whale, with a remark on the associated species. Sci Rep Whales Res Inst. 1976;28:153-60.

Mackintosh NA. The southern stocks of whalebone whale. Discov Rep. 1942;22:197-300.

Martins CCA, Morete ME, Engel MH, Freitas AC, Secchi ER, Kinas PG. Aspects of habitat use patterns of humpback whales in the Abrolhos Bank, Brazil, breeding ground. Mem Queensl Mus. 2001;47:83-90.

Martins CCA, Andriolo A, Engel MH, Kinas PG, Saito CH. Identifying priority areas for humpback whale conservation at Eastern Brazilian Coast. Ocean Coast Manag. 2013;75:63-71.

Nicol S. Krill, currents, and sea ice: Euphausia superba and its changing environment. Bioscience. 2006;56:111-20. 
Nogueira Jr M, Haddad MA. The diet of cubomedusae (Cnidaria, Cubozoa) in southern Brazil. Braz J Oceanogr. 2008;56:157-64.

Ortmann A. Decapoden und schizopoden. In: Hensen V, editor. Ergebnisse der plankton-expedition der Humboldt-stiftung. Kiel and Leipzig: Lipsius und Tischer; 1893. p. 1-120.

Peltier H, Dabin W, Daniel P, Van Canneyt O, Dorémus G, Huon M, et al. The significance of stranding data as indicators of cetacean populations at sea: modelling the drift of cetacean carcasses. Ecol Indic. 2012;18:278-90.

Pombo M, Denadai MR, Turra A. Seasonality, dietary overlap and the role of taxonomic resolution in the study of the diet of three congeneric fishes from a tropical bay. PLoS One. 2013;8:e56107.

Pomilla C, Amaral AR, Collins T, Minton G, Findlay K, Leslie MS, et al. The world's most isolated and distinct whale population? Humpback whales of the Arabian Sea. PLoS One. 2014;9:e114162.

Rohner CA, Armstrong AJ, Pierce SJ, Prebble CEM, Cagua EF, Cochran JEM, et al. Whale sharks target dense prey patches of sergestid shrimp off Tanzania. J Plankton Res. 2015;37:1-11.

Ruiz AE, Fondacaro RR. Diet of hake (Merluccius hubbsi Marini) in a spawning and nursery area within Patagonian shelf waters. Fish Res. 1997;30:157-60.

Stone GS, Katona SK, Tucker EB. History, migration and present status of humpback whales, Megaptera novaeangliae, at Bermuda. Biol Cons. 1987;42:122-45.

Swingle WM, Barco SG, Picthford TD, McLellan WA, Pabst DA. Appearance of juvenile humpback whales feeding in the nearshore waters of Virginia. Mar Mam Sci. 1993;9:309-15.

Van Waerebeek K, Baker AN, Félix F, Gedamke J, Iñiguez M, Sanino GP, et al. Vessel collisions with small cetaceans worldwide and with large whales in the Southern Hemisphere, an initial assessment. LAJAM. 2007;6:43-69.

Vikingsson GA. Feeding of fin whales (Balaenoptera physalus) off Iceland - diurnal and seasonal variation and possible rates. J Northwest Atl Fish Sci. 1997;22:77-89.

Ward E, Zerbini AN, Kinas PG, Engel MH, Andriolo A. Estimates of population growth rates of humpback whales (Megaptera novaeangliae) in the wintering grounds off the coast of Brazil (Breeding Stock A). J Cetac Res Manage. 2011:3:145-9.

Zerbini AN, Andriolo A, Heide-Jørgensen MP, Pizzorno JL, Maia YG, Van Blaricom GR, et al. Satellite-monitored movements of humpback whales Megaptera novaeangliae in the Southwest Atlantic Ocean. Mar Ecol: Prog Ser. 2006;313:295-304.

Zerbini AN, Ward E, Engel MH, Andriolo A, Kinas PG. A Bayesian assessment of the conservation status of humpback whales (Megaptera novaeangliae) in the Western South Atlantic Ocean (Breeding stock A). J Cetac Res Manage. 2011:3:131-44

\section{Submit your next manuscript to BioMed Central and we will help you at every step:}

- We accept pre-submission inquiries

- Our selector tool helps you to find the most relevant journal

- We provide round the clock customer support

- Convenient online submission

- Thorough peer review

- Inclusion in PubMed and all major indexing services

- Maximum visibility for your research

Submit your manuscript at www.biomedcentral.com/submit

CBiomed Central 